\title{
A Peer-Based Financial Planning \& Education Service Program: An Innovative Pedagogic Approach
}

\author{
Joseph W. Goetz, University of Georgia, USA \\ Dorothy B. Durband, Texas Tech University, USA \\ Ryan E. Halley, George Fox University, USA \\ Kimberlee Davis, Texas State University, San Marcos, USA
}

\begin{abstract}
This paper presents a peer-based financial planning and education program as a strategy to address the lack of financial literacy among college students and provide an experiential learning opportunity for students majoring in financial planning or other financial services-related disciplines. Benefits of such programs to campus communities are addressed by illustrating the current trends regarding student debt and financial literacy. The paper provides a specific description of a successful peer-to-peer financial planning and education program and encourages its replication at other colleges and universities. Through the review of this program, other schools may emulate effective strategies to assist in the implementation of this program as a pedagogical tool to improve students' educational experience.
\end{abstract}

Keywords: Financial education; financial planning; peer education; personal finance

\section{INTRODUCTION}

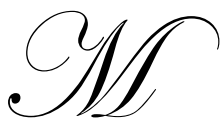

any students entering college are likely unprepared to manage the wide array of financial decisions they will face. Consequently, they are vulnerable to financial crises (Henry, Weber, \& Yarbrough, 2001; Joo, Grable, \& Bagwell, 2003). Results of research and statistics corroborate a low level of financial literacy and increasing level of debt among college students (Chen \& Volpe, 1998; Jump\$start Coalition, 2008; Mandell, 2002; Manning, 2000). These provide evidence supporting a strong argument for college students to have access to financial planning and counseling assistance, as well as exposure to financial education.

Without having exposure to financial education, many students fail to make optimal financial decisions (Adams \& Moore, 2007; Chen \& Volpe, 1998). When students find themselves in trouble with high levels of debt, they face a deluge of deleterious debt management schemes. These financial crises may cause feelings of hopelessness and significant distress among students. Financial-related stress has become increasingly common among students. For example, Phinney and Haas (2003) identified "financial stress" as one of the primary forms of stress experienced by minority college students. In addition, debt and financial stress can lead to decreased academic performance of all students (Pinto, Parente, \& Palmer, 2001; Ross, Niebling, \& Heckert, 1999; St. John, 1998). It can also lead to students dropping out of college in order to work additional hours to manage their debts. Both of these adversely affect retention rates at colleges and universities. When financially perplexed students are able to somehow manage increased work hours and remain in school, they may enroll in fewer academic hours, resulting in delayed graduation, which is a growing concern among leaders of higher education.

Students are taking on more debt in multiple forms, including car loans, student loans, and credit cards. Most undergraduate students (84\%) have at least one card and about half of all students have at least four credit cards (Sallie Mae, 2009). Survey data indicate a 46\% increase in credit card debt among college students since 2004 (Sallie Mae, 2009) and about half of new college graduates revolve a balance on one or more credit cards (ACE, 2006). The high use of credit cards often leads to incongruence between students' levels of income and amount of 
credit available to them. This proves problematic if a student is predisposed to overspending or lacks other financial resources (Chen \& Volpe, 1998). This relationship is further complicated when considering students' lack of financial management experience, escalating tuition costs, and other unforeseeable expenses. Consequently, many students are graduating with low credit scores, typically due to high levels of credit card debt and poor payment histories. Poor credit scores can impact employment opportunities. Housing choices may also be limited by poor credit scores since leasing and mortgage companies rely heavily on credit scores. A poor credit history can even lead to higher insurance premiums (Insurance Information Institute, 2011).

Research has shown there are some groups of students who are "financially at risk" for acquiring high levels of debt and mismanaging credit. Another trend on college campuses includes an increase in the number of financially independent students. This results in more students working to cover college expenses. These groups include women and minorities, low-income students, first-generation students, and financially independent students (Lyons, 2004). Of students who did not complete their college degrees, $43 \%$ of whites and $70 \%$ of minorities reported that debt prevented them from staying in school (Nellie Mae, 1998). Students' management of debt and related financial stress are issues that should be of great concern to colleges and universities.

One method to address the level of financial literacy and financial stress among students of higher education is peer financial planning and education programs. These programs can give students studying for careers in financial services an opportunity to gain practical experience and apply what they are learning in the classroom through educating and helping other students. A study conducted at a large southwestern university indicated that $91 \%$ of college students believed that financial counseling/planning services should be available for all students on campus and $48 \%$ reported that they would use such services (Moore, 2004). However, few programs of this type exist. Examples of a university-based, peer financial planning or education program are not currently available in the literature. This article provides an overview of a successful peer-to-peer financial planning and education program and provides a model of effective strategies to assist in the implementation of a financial planning and education program geared to the college student.

\section{Program Purpose}

The program described in this article operates at a large southwestern university, nevertheless its design is applicable to schools of varying enrollment size. The program has been in operation and has grown substantially over the past ten years. Since inception, the program has served thousands of members of the campus community through individual financial planning assistance and financial education seminars. Evaluations of participating students' presentations and one-on-one financial planning sessions have been consistently positive. The program began as a service exclusively for students. Due to requests for services by faculty and staff, the program expanded the scope of services to meet faculty and staff needs through the university Employee Assistance Program. The services currently offered are free to members of the university community.

The program's innovative approach encompasses two primary elements. First, the program provides students, faculty and staff with financial planning and education services to increase their level of financial knowledge and help them attain their financial goals. Second, the program facilitates the academic and professional development of undergraduate and graduate students majoring in personal financial planning and related disciplines. This allows students to apply learning achieved through traditional pedagogy to experiential learning opportunities. Such opportunities include working directly with clients and presenting financial education seminars. These two purposes guide the management and organization of the program.

Models for effective pedagogical strategies are needed to increase the success of financial planning programs (Martin, 2007). There are over one-hundred colleges and universities offering Certified Financial Planner Board of Standards registered programs of study specifically in financial planning. The program described in this paper is unique in the extent of applied experience provided to students. The program's design and practice is based on the models of peer-based education, service-learning, and Kolb's (1984) theory of experiential learning. 


\section{Peer-based Model}

According to social learning theory, students may learn best from models they see as similar to themselves; therefore, using peer educators that are similar to the target audience may improve the likelihood of students receiving the intended message (Fabiano, 1994; Sloane \& Zimmer, 1993). In addition, peer educators tend to serve as role models and activists on campus, sharing countless teachable moments with other students. Numerous articles have been published on the topic of peer-based counseling and education in high schools and colleges, and its practice is widely accepted and positive outcomes supported (see Cox, 1999; D'Andrea \& Salovey, 1996; Ender \& Newton, 2000; Nichols \& Lumley, 1999; Parkin \& McKeganey, 2000). The use of peer education models is increasingly common, as one study of undergraduate students in peer-to-peer assistance roles on campuses found that $76 \%$ to $83 \%$ of all higher education institutions use some form of peer educators in varied student services (Carns, Carns, \& Wright, 1993).

The peer-based model provides many benefits to the peer educators themselves. Research indicates that students who participate in peer education training and become peer educators derive a heightened sense of leadership, increased knowledge of the peer education topic, and positive behavior change (e.g., Badura, Millard, Peluso, \& Ortman, 2000; Klein, Sondag, \& Drolet, 1994). These students have an opportunity to apply what has been learned in the classroom and from additional targeted training. Based on experiential learning theory (Kolb, 1984), this creates an enhanced learning and developmental experience for student participants. In terms of peer financial planning, using a peer-based model gives students direct experience assisting clients with making financial decisions, solving real financial problems and meeting financial goals. Exposure to these clients fosters many of the skills needed by students to make a smooth transition to the professional world after they graduate, including increasing their marketability to prospective employers (Goetz, Tombs, \& Hampton, 2005).

\section{Program Structure}

Two primary components define the program's structure: (1) outreach-based financial planning and (2) client-based financial planning. The semantics of "financial planning" in this context refer to financial education as well as one-on-one financial planning assistance. Thus, the program's peer financial planners (PFPs) may assist individuals with either financial problems or financial goals that fall along a wide continuum of financial issues. For example, one client utilizing the service may require assistance with credit card debt management, whereas another client may request assistance in how to get started investing money for retirement, both of which can be addressed by a PFP. Peer financial planners may also help other students with filing taxes as part of the IRS Volunteer Income Tax Assistance (VITA) Program (see Palmer, Goetz, \& Chatterjee, 2009).

There is one faculty advisor to the program who assists with all management facets of the organization, including training and supervision of the PFPs. The academic department that houses the degree program of "personal financial planning" provides funds for two graduate assistants to aid the faculty advisor with the overall operations of the program and one undergraduate to fulfill administrative duties such as scheduling. The graduate assistants are typically doctoral students specializing in the area of financial planning. The program is primarily staffed by undergraduate and graduate students serving as the PFPs; they also are typically students who major or minor in finance, personal financial planning, accounting or another related field. Peer financial planners apply to be part of the program either as volunteers or as an enrollee of an elective practicum course; however, consent from the instructor of this course is required for registration.

Students volunteering to be peer financial planners may be involved in either one or both components of the program (i.e., outreach-based and/or client-based peer financial planning). Students involved in the outreachbased financial planning are required to complete a set number of financial education presentations per semester. This minimal requirement is fulfilled through either arranging a program on one's own or fulfilling a program request that comes through a scheduling coordinator. The scheduling coordinator receives calls for financial education presentation requests and individual client sessions, generated primarily from referrals and marketing materials disseminated on campus. Requests for presentations typically come from those teaching courses, student organization leaders, and residential life personnel; however, requests are also received from local community entities, such as churches, social services agencies, and secondary schools. 
Students involved in the program's outreach-based education component develop and facilitate presentations covering a variety of financial issues, such as: organizing finances and budgeting, managing credit card debt, saving and investing options, selecting and comparing employer provided benefits, identity theft, financial planning for after college, choosing a financial planner, tax strategies. Students involved in the program's clientbased component are required to be available for at least two on-call hours each week for the duration of a semester. Thus, when clients call for an appointment they can be scheduled immediately within a peer financial planner's preset time interval. This is a minimum requirement as volunteers may sign up to be available for additional hours. The PFPs are expected to be flexible in establishing their on-call hours in order to establish sufficient coverage to accommodate clients' requests for financial planning.

\section{Educational Benefits to Students}

Two parties benefit from this type of program: the student volunteers who staff the program and carry out its services, and the students from the campus community that receive its services. Student volunteers participating in this type of program develop many of the skills that will be needed after entering the workforce, such as sophisticated abilities in program development, client communication, and public speaking, which will serve to ease their transition into the professional world (Goetz et al., 2005). Students may apply hours of service toward the experience requirements for nationally recognized certifications in financial services such as the Certified Financial Planner ${ }^{\mathrm{TM}}(\mathrm{CFP} \AA)$, Accredited Financial Counselor (AFC), or Certified Retirement Counselor (CRC®) professional designations (Goetz et al., 2011). Another developmental benefit of the program is that it instills a sense of importance in community service and ethics among the students participating, consistent with the philosophy and pedagogy of service-learning (Jacoby, 1996, 2003; Palmer et al., 2009). Based on the service-learning model, volunteer peer financial planners learn effectively because they engage in activities that address a community need, and at the same time, participate in continuing education seminars where they take part in structured learning activities such as discussing client cases or presentation tactics. A peer-based program has both a didactic and altruistic purpose in that students' desire to help others yields a learning experience for them. Research corroborates the effectiveness of service-learning techniques, particularly in terms of promoting leadership development, teamwork, multicultural sensitivity, as well as the sense of social responsibility and ethics previously mentioned (Batchelder \& Root, 1994).

Those individuals who take advantage of the program's services derive multiple benefits. Participants leave a session with a greater sense of financial awareness and empowerment. Financial topics that seemed previously abstract and unattainable become clearer and more manageable. Client feedback reveals that the financial information shared often translates into the reduction of current financial problems and the prevention of future concerns, and related research would suggest that increased academic productivity and an enhanced financial wellbeing should follow (Pinto, Parente, \& Palmer, 2001; Ross, Niebling, \& Heckert, 1999; St. John, 1998).

\section{Recruitment and Staffing}

The majority of the program's personnel are students who major in personal financial planning or business related areas and complete prerequisite coursework. Most of these students are volunteers; however, a number of students participate as peer financial planners as part of their requirements for a practicum course in which they receive credit toward their degree. The practicum provides training for students to enhance their financial knowledge and client communication skills, and to become proficient in working with group audiences and integrating presentation techniques learned in the classroom.

Information is posted and announcements are made in various classes and organization meetings about the recruitment of new volunteers. Interested students complete an application and undergo an interview process. A benefit of using a volunteer peer-based model is the tendency toward positive self-selection. Those who possess either financial acumen or aptitude, and an affinity toward helping others are most likely to apply to the program and also most likely to benefit the program. Students are selected to be PFPs based on their past academic performance, fulfillment of course prerequisites, presentation/interpersonal skills, motivation, related experience, schedule availability and overall suitability for the program. Due to the course prerequisites, student volunteers typically are at the junior or senior level and already possess a base level of financial knowledge that prepares them, in part, for 
the outreach and client-based financial planning components of the organization. However, after selected to be a peer financial planner, student volunteers undergo additional training.

\section{Training}

New student recruits have completed the required coursework, which includes an introductory course in "financial planning" or "personal financial management" and a course in "financial counseling." The skills and knowledge acquired in these courses foster substantial preparation for work as a PFP. New recruits also fulfill additional training requirements prior to seeing clients or facilitating presentations. This training typically occurs early in the semester, over several days and covers topics such as: procedural measures, technology usage, plannerclient role plays, case studies, touring of client facilities, emergency protocol, liability issues, presentation tips and outlines, and how to handle the most common difficult scenarios and questions when with clients.

The various topics of the training are reinforced through an extensive training manual, as well as continuing education and training seminars that take place throughout each semester. Each of the aforementioned training topics are covered in the training manual and the importance of such a document cannot be overstressed. For example, the training manual clearly circumscribes what guidance can and cannot be given to clients, which is imperative to address liability concerns. Students should be cognizant of the boundaries of their responsibilities (e.g., confidentiality) and of limitations on the financial information they give to clients (e.g., investment education and general advising rather than specific mutual fund recommendations).

A continuing education requirement serves to keep volunteers and practicum students apprised of the evolving laws that affect financial decision-making and act as a tool to allow PFPs to learn from each other's experiences, as is typical practice in service-learning programs. For example, client cases and presentation experiences are discussed and used as a tool for learning. By meeting weekly and sharing previous experiences with each other, the entire staff is able to stay abreast of the financial issues that are most relevant to the student population. If a volunteer or student is unable to attend more than two continuing education trainings, he or she performs alternative service duties.

\section{Campus Partners}

The program's success is partly attributable to its ability to offer services in an accessible location on campus, and by collaborating with other campus programs and departments to maximize the effectiveness of outreach efforts. The primary partners of the program have been the Marriage \& Family Therapy Clinic, Office of Financial Aid, Student Legal Services program, the campus Federal Credit Union, Health Sciences Center/Medical School, and Department of Housing and Residential Life. The partners assist the program in terms of providing physical space for meeting with clients, and through providing training, presentation requests, and client referrals.

\section{RESEARCH OPPORTUNITIES}

Implementation of a peer-based financial planning and education program provides many opportunities for research. Empirical evidence is needed to demonstrate whether significant benefits exist for students participating in this type of program. Research as to the best methods of program evaluation and documentation of program evaluation results are needed to support the viability of this type of program. Best practices should be identified and documented in the literature. More specifically, process and outcome research is needed to improve the financial planning process. Research examining which particular educational topics are most salient to various audiences would also be beneficial.

\section{CONCLUSION}

The examples and recommendations in this article can be used to develop financial planning and education programs on other campuses. A number of books are currently available that may also assist with the development and implementation of peer-based financial service programs (i.e., Pulvino, Lee, \& Pulvino, 2002; Waddell, 2001; Wall, 2002; see also Ender \& Newton, 2000; Okun, 2002). A peer-based program may not necessarily require PFPs 
to be majors in financial planning, finance or business-related majors. Rather, any student who is equipped with the desire to learn about personal finance or to help others could potentially be a successful volunteer; however, students with a background in financial planning, finance, accounting or consumer economics are ideal.

The lack of financial literacy among college students is a problem of epidemic proportions and indicates a significant need for financial planning and education programs in university settings. Individuals who utilize a financial education program are more likely to be equipped with much of the financial knowledge and skills necessary to successfully address personal financial issues (Lyons, 2003). Programs of this type can easily be designed to be consistent with university missions of outreach, research, and teaching. It is also in line with college and university goals to increase retention rates and limit delayed graduation or academic interruption of students. Most importantly, it provides students a great opportunity to learn and develop professionally using pedagogic techniques that are theoretically supported.

\section{AUTHOR INFORMATION}

Joseph Goetz is an assistant professor of family financial planning at the University of Georgia. His research focuses on financial planning pedagogy, investment risk tolerance, and relational financial therapy. He received his $\mathrm{Ph} . \mathrm{D}$. degree in person financial planning from Texas Tech University. He is a founding board member of the Financial Therapy Association. He is a founding partner of E \& G Wealth Advisory Group, an independent financial planning and wealth management firm based in Athens, Georgia.

Dorothy B. Durband is Associate Professor of Personal Financial Planning and Associate Chair of the Department of Applied and Professional Studies at Texas Tech University in Lubbock, Texas. Durband also directs the operations of Red to Black ${ }^{\mathrm{TM}}$, a financial counseling program for Texas Tech students, faculty, and staff. She received a Ph.D. in Family Financial Management from Virginia Tech and holds a M.S. degree from Texas Woman's University and a B.S. from Louisiana State University. She is an Accredited Financial Counselor. Her research interests include college student financial behaviors, financial counseling techniques, and employee financial education.

Ryan Halley has been an Associate Professor of Finance in George Fox University's School of Business since 2009. He has been teaching full-time for the past six years. Ryan also has worked as a financial consultant for JP Morgan Chase, as a graduate research assistant at Texas Tech University and as a state auditor for the State of Ohio. Ryan earned a doctorate in consumer economics and personal financial planning from Texas Tech University and a MBA from The Ohio State University. He holds the Accredited Financial Counselor (AFC) designation from the Association for Financial Counseling and Planning Education.

Kimberlee Davis earned a M.Ed. in Counseling Education and a Ph.D. in Family and Consumer Sciences with an emphasis in Personal Financial Planning, both from Texas Tech University. Dr. Davis is certified as a National Certified Counselor by the National Board of Certified Counselors and an Accredited Financial Counselor by the Association of Financial Counseling and Planning Education. Currently Dr. Davis is an Assistant Professor at Texas State University at San Marcos. In addition to her teaching responsibilities in 2007 Dr. Davis started and continues to direct Money Savvy Cats, a peer-to-peer financial education program serving the university community.

\section{REFERENCES}

1. Adams, T., \& Moore, M. (2007). High-risk health and credit behavior among 18 to 25 year old college students. Journal of American College Health, 56(2), 101-108.

2. American Council on Education. (2006). Credit card ownership and behavior among traditional-age undergraduates, 2003-04. Retrieved July 17, 2006 from http://www.acenet.edu/AM/Template.cfm?Section=CPA

3. Batchelder, T., \& Root, S. (1994). Effects of an undergraduate program to integrate academic learning and service: cognitive, prosocial cognitive, and identity outcomes. Journal of Adolescence, 17(4), 341-355. 
4. Badura, A. S., Millard, M., Peluso, E. A., \& Ortman, N. (2000). Effects of peer education training on peer educators: Leadership, self-esteem, health knowledge, and health behaviors. Journal of College Student Development, 41, 471-478.

5. Carns, A. W., Carns, M. R., \& Wright, J. (1993). Students as paraprofessionals in four-year colleges and universities: Current practice compared to prior practice. Journal of College Student Development, 34, 358363.

6. Chen, H., \& Volpe, R. P. (1998). An analysis of personal financial literacy among college students. Financial Services Review, 7(2), p107-128.

7. Cox, J. R. (1999). A guide to peer counseling. Lanham, MD: Rowman \& Littlefield.

8. D'Andrea, V. J., \& Salovey, P. (Eds.). (1996). Peer counseling: Skills, ethics, and perspectives. (2 ${ }^{\mathrm{nd}}$. ed.). Palo Alto, CA: Science \& Behavior Books.

9. Ender, S. C., \& Newton, F. C. (2000). Students helping students: A guide for peer educators on college campuses. New York: John Wiley \& Sons.

10. Fabiano, P. M. (1994). From personal health into community action: Another step forward in peer health education. Journal of American College Health, 43, 115-121.

11. Goetz, J., Zhu, D., Hampton, V., Chatterjee, S., \& Salter, J. (2011). Integration of professional certification examinations with the financial planning curriculum: Increasing efficiency, motivation, and professional success. American Journal of Business Education. Manuscript in press.

12. Goetz, J. W., Tombs, J. W, \& Hampton, V. (2005). Easing college students' transition into the financial planning profession. Financial Services Review, 14(3), 231-251.

13. Henry, R. A., Weber, J. G., Yarbrough, D. (2001) Money management practices of college students. College Student Journal, 4, 244-247.

14. Insurance Information Institute. (2011, January). Credit scoring. Retrieved January 16, 2011 from http://www.iii.org/media/hottopics/insurance/creditscoring

15. Jacoby, B. (1996). Service-learning in higher education: concepts and practices. San Francisco: JosseyBass.

16. Jacoby, B. (Ed.). (2003). Building partnerships for service-learning. San Francisco: Jossey-Bass.

17. Joo, S., Grable, J. E., \& Bagwell, D. C. (2003). Credit card attitudes and behaviors of college students. College Student Journal 37, 405-419.

18. Jump\$tart Coalition for Personal Financial Literacy. (2008). 2008 Survey of Financial Literacy among College Students. Retrieved January 17, 2011, from http://www.jumpstart.org/survey.html

19. Klein, N. A., Sondag, K. A., \& Drolet, J. C. (1994). Understanding volunteer peer health educators' motivations: applying social learning theory. Journal of American College Health, 43(3), 126-130.

20. Kolb, D. A. (1984). Experiential learning: Experiences as a source of learning and development. Englewood Cliffs, NJ: Prentice-Hall.

21. Lyons, A. C. (2004). A profile of financially at-risk college students. Journal of Consumer Affairs, 38(1), 56-80.

22. Lyons, A. C., Hogarth, J., Schuchardt, J., Smith, T., \& Tousaaint-Comeau, M. (2003). Evaluating outcomes of personal financial education. Consumer Interests Annual, 49, 1-3.

23. Mandell, L. (2002). Financial literacy: A growing problem. Washington, D.C.: Jump\$tart Coalition for Personal Financial Literacy.

24. Manning, R. D. (2000). Credit card nation: The consequences of America's addiction to credit. New York: Basic Books.

25. Martin, C. L. (2007). Developing a personal financial planning program: More than just Courses. Journal of College Teaching \& Learning, 4(11), 79-84.

26. Moore, R. (2004). Credit card knowledge, attitudes, and practices of college students. Unpublished doctoral dissertation, Texas Tech University.

27. Nellie Mae Corporation. (1998). Life after debt: Report of the national student loan survey. Braintree, MA: Nellie Mae Corporation. Retrieved January 16, 2011, from http://www.nelliemae.com/library/NASLS.pdf

28. Nellie Mae Corporation. (2002). Undergraduate students and credit cards: An analysis of usage rates and trends. Braintree, MA: Nellie Mae Corporation. Retrieved July 13, 2005, from http://www.nelliemae.com/library/ccstudy_2001.pdf 
29. Nellie Mae Corporation. (2005). Undergraduate students and credit cards in 2004: An analysis of usage rates and trends. Braintree, MA: Nellie Mae Corporation. Retrieved January 14, 2011, from http://www.nelliemae.com/library/ccstudy_2005.pdf

30. Nichols, L., \& Lumley, L. (1999). Involving students in the development of a peer education program for college women. Journal of College Student Development, 40, 422-427.

31. Okun, B. F. (2002). Effective helping: Interviewing and counseling techniques. (6 ${ }^{\text {th }}$ ed.). Pacific Grove, CA: Brooks Cole.

32. Palmer, L., Goetz, J., \& Chatterjee, S. (2009). Service-Learning for financial planning students: Making a difference now and for years to come. Financial Services Review, 18(2), 157-175.

33. Parkin, S. \& McKeganey, N. (2000). The rise and rise of peer education approaches. Drugs: Education, Prevention and Policy, 7(3), 293-310.

34. Phinney, J. S., \& Hass, K. (2003). The process of coping among ethnic minority first-generation college freshmen: A narrative approach. Journal of Social Psychology, 143, 707-726.

35. Pinto, M. B., Parente, D. H., \& Palmer, T. S. (2001). College student performance and credit card usage. Journal of College Student Development, 42(1), 49.

36. Pulvino, C., Lee, J. L., \& Pulvino, C. A. (2002). Financial counseling: A strategic approach ( $2^{\text {nd }}$ ed.). Madison, WI: Instructional Enterprises.

37. Ross, S. E., Niebling, B. C., Heckert, T. M. (1999). Sources of stress among college students. College Student Journal, 33, 312-317.

38. Sallie Mae. (2009). How undergraduate students use credit cards. Wilkes-Barre, PA: Sallie Mae, Inc.

39. Sloane, B. C., \& Zimmer, C. G. (1993). The power of peer health education. Journal of American College Health, 41, 241-245.

40. St. John, E. (1998). Loan debt: A new view. Black Issues in Higher Education, 15 (10), 16.

41. Waddell, F. E. (2001). Solution focused financial counseling in the new millennium. Moneta, VA: Genesis Press.

42. Wall, R. W. (2002). Financial counseling in practice: A practical guide for leading others to financial wellness. Honolulu: HI: Financial Wellness Associates. 